\title{
A "NAÇÃO MAZZINIANA" CHEGA À REGIÃO PLATINA: JORNALISTAS ITALIANOS E OS DEBATES NO PRATA EM MEADOS DO SÉCULO XIX
}

\author{
Eduardo Scheidt \\ Programa de Mestrado em História da Universidade Severino Sombra \\ Universidade Gama Filho
}

\section{Resumo}

Neste artigo, analisamos a atuação de dois jornalistas italianos, Gian Battista Cuneo e Luigi Rossetti, na Região Platina entre os anos de 1838 e 1860. Enfocando suas participações nos debates acerca da construção das nações na América, analisamos em que medida os autores modificaram e readaptaram suas idéias radicais, inspiradas no nacionalismo mazziniano, ao longo de suas atuações na imprensa da Região Platina.

\section{Pallavras-Chave}

Circulação de Idéias • Construção da Nação • Região Platina

\section{Abstract}

This article deals with the actuation of two Italian journalists, Gian Battista Cuneo and Luigi Rossetti, in the Río de la Plata Region, since 1838 to 1860. With the focus in their participation in the discussion about construct of the nation in America, we have analyzed how they have changed their radical ideas, inspirited in Mazzini's nationalism, during their work in newspapers of the Río de la Plata Region.

\section{Keywords}

Circulation of ideas $\bullet$ Construct of the Nation • Río de la Plata Region 
O presente artigo versa sobre a atuação de dois jornalistas italianos, Gian Battista Cuneo e Luigi Rossetti, na Região Platina ${ }^{1}$ em meados do século XIX. Os dois foram refugiados políticos que, ao serem obrigados a buscar exílio devido a perseguições da "Santa Aliança", estabeleceram-se na América, integrando-se às lutas políticas locais. O primeiro se radicou inicialmente em Montevidéu, onde se vinculou aos círculos intelectuais, especialmente aos jovens da Geração de $1837^{2}$, enquanto o segundo prestou serviços para os farroupilhas, inclusive como fundador do primeiro periódico oficial da então República RioGrandense. Por um curto período, Cuneo também esteve no Rio Grande do

\footnotetext{
${ }^{1}$ A "Região Platina", nosso espaço de análise, corresponde aos atuais territórios do Uruguai, do pampa argentino e da campanha sul-rio-grandense. Fundamentamo-nos no conceito de região desenvolvido pelas historiadoras Heloisa Reichel e Ieda Gutfreind, em sua obra As raízes históricas do Mercosul: a Região Platina colonial. São Leopoldo: UNISINOS, 1996. Conforme as autoras, aqueles territórios constituíam-se, na época colonial, em uma unidade econômica, social e cultural, denominada de "Região Platina". A região começou a se fragmentar a partir do final da era colonial, quando o escravismo expandia-se no Rio Grande do Sul, enquanto a área de colonização espanhola avançava na transição ao capitalismo. Após a independência, com o início do processo de formação dos novos Estados, a fragmentação da Região Platina acentuou-se. Segundo Reichel e Gutfreind, entretanto, manteve-se a unidade em torno da cultura popular, com hábitos, costumes e valores comuns, tornando o uso do conceito de Região Platina pertinente, mesmo para períodos posteriores ao colonial. Além da manutenção destes elementos da cultura popular, contatos entre as populações rio-grandenses e rio-platenses, especialmente no que se refere às relações comerciais e políticas, foram constantes ao longo do período de nossa investigação. O uso do conceito de região, desta forma, rompe com a prática predominante da historiografia de limitar os estudos no interior do espaço delimitado pelas fronteiras nacionais. A história regional tem demonstrado que, muito além de uma demarcação de limites, a fronteira é um espaço de intercâmbios comerciais, humanos e de idéias, em que as sociedades estabelecem trocas mútuas.

${ }^{2} \mathrm{O}$ grupo de intelectuais, posteriormente conhecido como Geração de 1837 , surgiu a partir de um pequeno número de jovens, dissidentes do regime rosista, que fundaram, naquele ano, o "Salão Literário" em Buenos Aires e designaram a si mesmos como a "Nova Geração". No ano seguinte, o grupo criou uma sociedade secreta, a "Jovem Argentina". Devido às perseguições promovidas pelo regime, a maior parte dos integrantes do grupo refugiou-se em Montevidéu a partir de 1838, onde fundaram a "Associação de Maio" e iniciaram uma intensa atividade de oposição a Rosas na imprensa local. O grupo foi influenciado pelo romantismo europeu, principalmente por autores como Saint-Simon, Pierre Leroux, Lamennais e Giuseppe Mazzini. Suas obras caracterizaram-se por críticas tanto aos unitários quanto aos federalistas, propondo-se a criação de uma "associação", que traria o progresso e a civilização. Passaram a criticar a pura "importação" de idéias, defendendo a necessidade de se estudar a realidade local. Sob inspiração dos românticos europeus, os integrantes da Geração de 1837 defendiam a expressão das "individualidades nacionais". Da mesma forma que as pessoas na sociedade, entretanto o grupo propunha que as nações se associassem entre si, em prol da fraternidade humana. Os principais intelectuais do grupo foram, entre outros, os argentinos Esteban Echeverría, Juan Bautista Alberdi, Juan Cruz Varela, Miguel Cané e o uruguaio André Lamas.
} 
Sul, trabalhando na imprensa farroupilha em 1840. Após 1852, ele se estabeleceu em Buenos Aires, contribuindo para a imprensa local ao lado dos liberais que assumiram o poder após a queda do então governador da província Juan Manuel de Rosas. O período que vai de 1838, ano em que Cuneo e Rossetti começaram a atuar como jornalistas, até 1848, quando Cuneo retornou à Itália para participar das revoluções de 1848 e 1849, corresponde ao primeiro momento da "nação mazziniana" na Região Platina. Durante o período, Rossetti faleceu em uma batalha entre os farroupilhas e os imperiais em fins de 1840. Identificamos um segundo período de atuação do jornalismo mazziniano na região, protagonizado unicamente por Cuneo, a partir de 1853, em seu novo exílio na América. Nesta ocasião, ele se radicou em Buenos Aires até 1860, ano em que retornou definitivamente para a Itália.

Gian Battista Cuneo nasceu na cidade italiana de Oneglia no ano de 1809. Em 1833, mudou-se para Nice, onde foi preso, acusado de difundir escritos revolucionários, mas conseguiu escapar milagrosamente. No ano seguinte, envolveu-se com os preparativos insurrecionais de Gênova, promovidos pela "Jovem Itália", sociedade secreta fundada por Giuseppe Mazzini à qual Cuneo era filiado. Perseguido, foi obrigado a se refugiar, primeiro na França e, em seguida na América, estabelecendo-se no Rio de Janeiro em 1835, onde conheceu, entre outros, seus conterrâneos Giuseppe Garibaldi e Luigi Rossetti. Não há dados confiáveis na historiografia acerca da vida de Rossetti na Itália. Com certeza, sabe-se apenas que ele era genovês e estava radicado no Rio de Janeiro desde 1827. Na capital do então Império do Brasil, Cuneo logo entrou em contato com a incipiente comunidade italiana local, composta basicamente por comerciantes e exilados políticos, junto aos quais fundou uma filial da Jovem Itália. Ainda no Rio de Janeiro, deu vida, no ano de 1836, a um periódico em língua italiana, intitulado La giovine Italia, do qual só se conhece o "manifesto-programa" e duas primeiras edições. Também, no Rio, nossos personagens ouviram falar de um outro conterrâneo, Tito Livio Zambeccari, que tinha chegado à capital imperial em fins de 1836 como prisioneiro, devido ao seu envolvimento na Revolução Farroupilha, sendo confinado na Fortaleza de Santa Cruz. Garibaldi e Rossetti passaram a visitar o conterrâneo na prisão. Através dos contatos durante as visitas, estes souberam por meio de Zambeccari dos acontecimentos no Rio Grande do Sul, decidindo prestar serviços à causa farroupilha. Desta forma, Rossetti e Garibaldi entraram em contato com os revolucionários rio-grandenses, optando por partir rumo à República RioGrandense no ano seguinte. Em 07 de maio de 1837 eles partiram da Baía da 
Guanabara, a bordo da nave "Mazzini”, em direção à Região Platina, chegando ao porto de Montevidéu em meados do mesmo ano. Cuneo também tomou a mesma embarcação, aportando na capital uruguaia a 16 de julho de 1837.

Em nossa investigação, analisamos as contribuições dos personagens para os debates sobre a questão nacional, entre os anos de 1838 e 1860, em meio ao tumultuado período de construção dos Estados na região. Processo complexo, conturbado, vivido de diferentes maneiras conforme distintos sujeitos históricos, o surgimento de nações é tema de crescente relevância na historiografia política recente. Embora marcado por inúmeras dificuldades, os estudos sobre a nação têm suscitado interesses cada vez maiores entre os pesquisadores. Na Argentina, por exemplo, a questão das origens da nação voltou a ser discutida a partir das pesquisas renovadoras do historiador José Carlos Chiaramonte ${ }^{3}$, que lançou a tese de que as nacionalidades latino-americanas, ao contrário do que a historiografia costumava afirmar até então, seriam inexistentes na época da independência e primeiras décadas posteriores. Conforme o autor, prevaleciam as identidades locais, logo provinciais, além de uma identidade americana. Na prática, as províncias permaneceram soberanas e independentes ao longo de várias décadas. Os posicionamentos de Chiaramonte têm estimulado polêmicas, como o debate com a historiadora Pilar Gonzáles Bernaldo ${ }^{4}$, autora de um artigo no qual discorda do seu colega, argumentando que a questão da nação já teria importante relevância no momento da emancipação, embora com significados bastante distintos dos momentos históricos posteriores ${ }^{5}$.

\footnotetext{
${ }^{3}$ CHIARAMONTE, José Carlos. El mito de los origenes en la historiografia latinoamericana. Cuadernos del Instituto Ravignani, n. 2. Buenos Aires: Instituto de Historia Argentina y Americana Dr. Emilio Ravignani, 1991.

${ }^{4}$ GONZÁLES BERNALDO, Pilar. La “identidad nacional” en el Río de la Plata post-colonial: continuidades y rupturas com el antiguo régimen. In: Anuario del IEHS “Prof. Juan C. Grosso”, n. 12. Tandil: Universidad Nacional del Centro de la Provincia de Buenos Aires, 1997, p. 109- 122.

${ }^{5}$ Diante de tais controvérsias, acreditamos que os posicionamentos de ambos os autores têm relevância. "Nação", na primeira metade do século XIX, tinha diversos significados, desde algo similar ao de "Estado", conforme esclareceu Chiaramonte, até o de uma "comunidade política", como argumentou Gonzáles Bernaldo. Chiaramonte, ainda que tenha afirmado que, via de regra, "nação" significava quase o mesmo que "Estado", não deixou de perceber outros significados daquele vocábulo, como a de uma "comunidade cultural hispano-americana" ou a "reunião de vários Estados". Ver CHIARAMONTE, José Carlos. Ciudades, provincias, Estados: orígenes de la Nación Argentina (1800-1846). Buenos Aires: Ariel, 1997. Por outro lado, a argumentação de Gonzáles Bernaldo, a nosso ver, sugere um peso muito excessivo às identidades nacionais do período. Neste sentido, concordamos com as argumentações de Chiaramonte de que prevaleciam, na época, as identidades locais e a identidade americana.
} 
Um dos propósitos centrais deste estudo é analisar a circulação de idéias nos debates sobre a construção da nação. Enfocando a participação dos italianos nestas discussões, procuramos analisar em que medida Cuneo e Rossetti modificaram e readaptaram suas idéias, ao longo de suas atuações na imprensa da Região Platina. Embora mazzinianos ${ }^{6}$ convictos e com o intuito inicial de divulgar seu ideário junto aos habitantes locais, partimos da hipótese de que nossos autores tiveram que "se ajustar" ao novo contexto.

Neste sentido, contestamos as abordagens historiográficas tradicionais, que tratam a circulação de idéias no sentido de transposição de ideários da Europa para América e/ou "influências" de idéias estrangeiras em nosso continente ${ }^{7}$

\footnotetext{
${ }^{6} \mathrm{O}$ termo refere-se ao ideário do italiano Giuseppe Mazzini, destacado líder da luta pela unificação italiana durante o século XIX. Partidário da via revolucionária, Mazzini fundou, em 1831, a sociedade secreta "Jovem Itália", com o intuito de organizar política e ideologicamente seus compatriotas. No campo das idéias, ele elaborou uma representação singular de nação, de cunho radical, calcada fundamentalmente em critérios políticos, na igualdade social e na fraternidade entre os diferentes povos. Sob sua perspectiva, os homens conquistariam a "nação" através da revolução contra os regimes despóticos. De conteúdo messiânico, seu ideário via na construção da nação a realização da "vontade divina" de que todos os homens fossem livres e iguais. Ao propor o futuro da humanidade organizado em comunidades nacionais, o autor se identificou com o projeto da "modernidade política" e do "princípio das nacionalidades". Entretanto, entendemos que Mazzini era também um crítico de alguns aspetos destes projetos, em especial ao excesso de individualismo da maioria dos liberais que, conforme as críticas do autor, conduziria os homens ao egoísmo e à desigualdade. Valendo-se de aspirações do romantismo, a proposta mazziniana pregava a revolução contra regimes despóticos, a plena igualdade entre os homens e a associação fraterna entre as nações. Neste sentido, o autor caracterizou-se por uma proposta singular que, ao combinar elementos liberais com românticos, inseriu-se no conjunto de projetos políticos modernos, na medida em que pregava o fim dos regimes despóticos e a soberania da nação, mas também criticava e distanciava-se dos mesmos, propondo alternativas.

${ }^{7}$ A tese da mera "importação" de idéias nasceu com o surgimento das próprias historiografias nacionais dos países latino-americanos no século XX, tendo grande continuidade no XX. Esta perspectiva persiste até em alguns trabalhos historiográficos produzidos nas últimas décadas. É o caso, ao nosso ver, da obra organizada por BETHELL, Leslie. (org.). História da América Latina. Vol. 3: da Independência até 1870. São Paulo/Brasília: Edusp/Imprensa Oficial/Funag, 2001, recentemente traduzida para o português e bastante utilizada em muitos cursos sobre América Latina em nosso país. Em um capítulo sobre as idéias políticas durante o século XIX na América Hispânica, Frank Safford trata da circulação de idéias de uma forma que pouco se diferencia da historiografia tradicional. Para o autor, a Espanha "moldou" as instituições políticas americanas durante a época colonial, assim como, transferiu para suas colônias o mesmo conjunto de idéias da metrópole. O processo de independência teria sido impulsionado pelas idéias liberais da Europa "moderna", França e Inglaterra no caso, contra a Espanha. Portanto, para o autor, são os acontecimentos europeus que determinam a história latino-americana; idéias e instituições estrangeiras serviriam de modelo às elites locais, sem espaço para elaborações próprias. Quando se tornam inevitáveis as referências às especificidades da América Hispânica, Safford afirma a existência de um "descompasso" entre as idéias européias defendidas pela elite e a realidade histórica, levando à noção de "idéias fora do lugar", bastante recorrente neste tipo de abordagem.
} 
É recorrente, naquelas produções historiográficas, a defesa da tese de "importação" de idéias, indicando a noção de que os agentes históricos latino-americanos seriam incapazes de produção intelectual e, em última instância, de fazer sua própria história. Em contraposição a esta perspectiva, fundamentamo-nos em Mary Louise Pratt especialmente em sua obra sobre viajantes estrangeiros na América Latina ${ }^{8}$.

Para a autora, é equivocado falar em transplante de elementos culturais da Europa para a América, uma vez que, ao chegarem ao continente americano, eles entram em contato com o contexto local, fenômeno que a autora designa

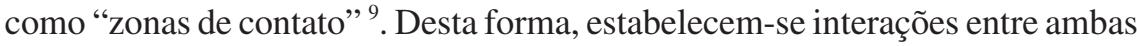
as culturas, processo em que os elementos culturais entrelaçam-se e chocamse uns com os outros, cujos resultados levam a uma síntese de algo novo, fruto da "transculturação 10 ".

\section{II}

Conforme mencionado, Cuneo e Rossetti chegaram a Montevidéu em meados de 1837. Em seguida, porém, os amigos italianos se separaram. Enquanto o primeiro permaneceu na capital oriental, o outro partiu rumo ao Rio Grande do Sul, onde iria participar da fundação do primeiro periódico oficial da nova república emergente na região.

Ao pisar em terras uruguaias, Cuneo se deparou com uma situação política bastante explosiva, na qual se mesclavam e se confundiam conflitos internos da jovem República do Uruguai com o cenário conturbado do conjunto da Região Platina. Neste sentido, as lutas entre os grupos políticos, liderados pelo

\footnotetext{
${ }^{8}$ PRATT, Mary Louise. Os olhos do império: relatos de viagem e transculturação. Bauru: EDUSC, 1999.

${ }^{9}$ Idem, ibidem, p. 27.

${ }^{10}$ A autora esclarece que o conceito de "transculturação" foi cunhado pelo sociólogo cubano Fernando Ortiz na década de 1940 (Idem, ibidem, p. 30). Para mais detalhes sobre a origem e utilização do conceito, ver ORTIZ, Fernando. Contrapunteo cubano del tabaco y el azucar. Habana: Consejo Nacional de Cultura La Habana, 1963. Segundo a definição do autor: "Hemos escogido el vocabulo transculturación para expresar los variadísimos fenómenos que se originan en Cuba por las complejísimas transmutaciones de culturas que aquí se verifican, sin conocer las cuales, es imposible entender la evolución del pueblo cubano, así en lo económico como en lo institucional, jurídico-ético, religioso, artístico, linguístico, psicológico, sexual y en los demás aspectos de su vida." (Idem, ibidem, p. 99).
} 
então presidente Manuel Oribe, por um lado, e pelo ex-presidente Frutuoso Rivera, por outro, interagiam com os conflitos entre rosistas e anti-rosistas na outra margem do Rio da Prata e entre farroupilhas e imperiais no território sul-rio-grandense. Além disto, desde a ascensão de Juan Manuel de Rosas em 1829, tinham começado a chegar de Buenos Aires sucessivas ondas de refugiados políticos diversos, como unitários, federalistas anti-rosistas e, em pouco tempo, juntaram-se a eles jovens intelectuais da Geração de 1837.

Em meio às lutas entre as facções, circulavam distintas propostas de construção do Estado e concepções de nação. Os governos de Buenos Aires e do Rio de Janeiro tinham projetos de centralização política, que se confrontavam com as lutas das províncias e dos pequenos Estados pela manutenção de suas autonomias. Neste sentido, as propostas federativas das províncias do Litoral argentino e do Rio Grande do Sul, bem como do Estado Oriental, compartilhavam do intuito de manter e, inclusive, incrementar as soberanias locais, entendendo a união federativa como uma tênue aliança. Por outro lado, Buenos Aires e Rio de Janeiro buscavam suas soberanias para o conjunto dos territórios reivindicados pelos países. Com a proclamação da República Rio-Grandense, seus protagonistas identificaram a "nação" como um pequeno Estado, livre e soberano, a exemplo do ocorrido no Uruguai anos antes.

Cuneo inicialmente entrou em contato com Miguel Cané, com quem estabeleceu uma forte amizade e obteve acesso ao círculo de proscritos argentinos. Cané foi seduzido pelas idéias igualitárias e radicais do nacionalismo mazziniano, procurando difundir o ideário entre seus correligionários. Segundo Jorge Mayer, o periodista italiano seria "agente de Mazzini” e teria fornecido documentos da Jovem Itália ao argentino, o qual teria tratado de repassar a seus compatriotas fundadores da "Nova Geração" 11 .

Nosso personagem iniciou seu trabalho como jornalista em 1838, no periódico El Iniciador ${ }^{12}$, fundado pelos intelectuais da Geração de 37. Apesar de

\footnotetext{
${ }^{11}$ MAYER, Jorge M. Alberdi y su tiempo. Buenos Aires: Editorial Universitaria de Buenos Aires, 1963, p. 156.

${ }^{12}$ El Iniciador começou a circular em 15 de abril de 1838. Com periodicidade quinzenal, a publicação foi fundada por Cané e o uruguaio Andrés Lamas, convertido ao ideário da Geração de 1837. Um dos objetivos principais do periódico era ser um espaço de expressão das idéias de intelectuais do grupo, que tinham ficado desprovidos de divulgarem seus escritos por este meio desde o fechamento do jornal portenho La Moda. Eram publicados, no Iniciador, além de
} 
escrever como se fosse um representante da juventude rio-platense, Cuneo procurou divulgar, ao longo de seus artigos, o ideário mazziniano, inclusive fazendo menções diretas a seu mestre, conforme o seguinte trecho de seu escrito $\mathrm{He}$ leido el Iniciador:

La historia, ha dicho Mazzini, es un gran libro, en el que cada siglo viene a escribir su renglón: y cada renglón de los siglos es una expresión diversa y progresiva de la inteligencia que se desarrolla; luego es certo que a la humanidad le son necesarias verdades nuevas, y más que cierto esencial que se dirija a descubrirlas para formular las leyes que deberán gobernarla. ${ }^{13}$

Neste sentido, o jornalista italiano buscou reproduzir as concepções fundamentais do nacionalismo de Mazzini. Compartilhando de seu messianismo, nosso autor fez diversas menções à "missão" que os homens teriam sido levados a cumprir por vontade divina. Além da harmonia entre as nações, outra tônica nas idéias dos mazzinianos era o conteúdo igualitário de suas propostas, levando-os a criticar o individualismo dos liberais, o qual, segundo eles, tornava os homens egoístas. Esse igualitarismo não poderia faltar nos argumentos do jornalista italiano, conforme é ressaltado no trecho abaixo:

Es necesario para juzgar exactamente de [sic] las cosas mirarlas de lo alto, subir hasta los principios generales que las dominan y no esclavisarnos a los hechos. A que puede conducir esta tendencia ciega, individual, mezquina? - Al egoismo, à la duda, al llenarmos el alma de las miserias de la infamia, e envilecernos a nosotros mismos. Toda época está dominada por una gran síntesis. La síntesis que a la nuestra domina es el progreso continuo. ${ }^{14}$

artigos de conteúdo político, muitos textos sobre literatura, música e poesia, identificados com o movimento romântico. Cada exemplar do periódico contava com um grande número de páginas, sendo composto, portanto, também de textos bastante longos, fugindo ao padrão da maioria dos jornais da época. A despeito da repressão, fazia-se circular o jornal também em Buenos Aires, onde a publicação tinha muitos leitores. Além de seus dois editores, o Iniciador contava com as contribuições de, entre outros, Juan Bautista Alberdi, Esteban Echeverría, Bartolomé Mitre, Carlos Tejedor, Félix Frias, Juan Maria Gutiérrez, além de Cuneo.

${ }^{13}$ El Iniciador, n. ${ }^{\circ} 3$, Montevidéu, 15/05/1838, p. 60.

${ }^{14}$ Idem, Ibidem, p. 62. 
Cuneo reproduzia, desta forma, a concepção nacionalista mazziniana, conforme a qual, a nação seria uma associação política, fundada livremente por seus cidadãos, cujas inspirações remetem à Revolução Francesa e à modernidade política $^{15}$. Entretanto, ao mesmo tempo em que se inseria nesta modernidade, o ideário de Mazzini tecia críticas a seus limites, em especial ao individualismo (ou egoísmo) concomitante às transformações sociais da época. Neste sentido, o igualitarismo apregoado pelos filiados da Jovem Itália é caracterizado como uma das formas mais radicais de se pensar e propor mudanças à sociedade de seu tempo.

O jornalista italiano buscou incutir nos jovens intelectuais rio-platenses o desejo de seguir o exemplo da "Jovem Europa", organizando-se para lutar pela nação livre e igualitária em todos os cantos do mundo. Isto não significa, entretanto, que nosso personagem fizesse um mero transplante das concepções de Mazzini para seus artigos publicados no Iniciador. Ao mesmo tempo em que procurava divulgar o nacionalismo mazziniano, percebemos, nos escritos de Cuneo, uma notória adaptação ao contexto intelectual local, incorporando concepções típicas dos “jovens de 37”. No mesmo artigo anteriormente citado, por exemplo, o jornalista italiano afirmou que:

Todo lo que pretendemos hacer es una continuación de lo que hicieran nuestros padres. [...]. Nosotros tenemos ya una Patria, que nadie podrá quitarnos jamás; pero ¿podremos decir que tenemos libre e independiente el pensamiento? No, aún pesan sobre nosotros los restos de una educación material, falsa, retrograda, las preocupaciones, las necesidades, los descarrios de una edad bárbara. Nuestras costumbres, nuestras leyes, nuestra literatura lo justifican. [...]. No sereis libres en tanto que nuestra inteligencia permanezca esclava del error? La verdadera libertad es la Razón. La razón es el espíritu de Dios por ella comprendereis que la misión del hombre en la tierra es la de obrar el bien por su conciencia, y que él es responsable de cuanto allí haga porque es libre; que los hombres son iguales y hermanos, como lo son todos los pueblos de la tierra; [...]. ${ }^{16}$

\footnotetext{
${ }^{15}$ Entendemos por modernidade política o conjunto de idéias e propostas políticas surgidas nos séculos XVII e XVIII, entre os iluministas e em oposição às práticas então regentes pela maioria dos governos, de cunho absolutista. As propostas modernas, pois, são aquelas calcadas no contratualismo, entendendo o governo como expressão da vontade popular, rompendo com a perspectiva de que as pessoas fossem súditas dos reis e suscetíveis às suas vontades. Os governos que se instalaram a partir da Revolução Francesa, da Independência dos EUA e dos países latino-americanos procuraram colocar em prática muitas ou parte das propostas iluministas.
}

${ }^{16}$ Idem, Ibidem, p. 59-60. 
Nosso autor assumiu, pois, idéias centrais do pensamento da Geração de 1837, em especial a concepção de que os protagonistas de "maio de 1810"17 tinham fundado a "pátria" com a revolução de independência, mas "hábitos e costumes da era colonial" persistiam, o que explicava o fato de o país ainda não ser "livre". A liberdade só se consumaria através de uma nova revolução, que a conquistaria, entre outros aspectos; "inteligência", leis e literatura próprias.

Os intelectuais de 37 romperam com a concepção predominante na época de tomar a "nação" como sinônimo de Estado, ou seja, uma associação política e soberana criada pelos homens através de um pacto voluntário. Leitores dos românticos, eles viam a necessidade de laços mais fortes entre as pessoas para efetivamente se constituir uma nação. Entre estes laços, destacava-se a consciência dos elementos de uma nacionalidade, tais como literatura, leis, hábitos, idéias e costumes. Entretanto, salientamos que, para os intelectuais do grupo, os laços que unem uma nacionalidade eram essencialmente políticos e culturais, tais como um ideário, uma literatura e costumes em comum. Não havia, ao contrário do que passava a ser apregoado entre os românticos europeus, referências a questões como língua, "raça" ou religião para caracterizar uma nação. Realizando leituras particulares das idéias européias e adaptando-as ao contexto rio-platense, os integrantes da Geração de 1837 foram, a nosso ver, artífices de um pensamento original sobre a nação, propondo alternativas inovadoras para a construção do Estado nacional.

Com o fim da circulação do Iniciador, em janeiro de 1839, os “jovens de 37" passaram a divulgar suas idéias em artigos publicados em um outro periódico, denominado El Nacional ${ }^{18}$. É certo que houve contribuições esporádicas

\footnotetext{
${ }^{17}$ A data alude ao movimento desencadeado pelo Cabildo de Buenos Aires em 25 de maio de 1810 que instalou uma Junta de governo, formada por representantes das elites criollas locais, que não reconheciam o novo governo espanhol, títere de Napoleão. Embora a Junta governasse em nome do rei Fernando VII, feito prisioneiro pelos invasores franceses, na prática representou um governo autônomo dos criollos, daí o "Movimento de Maio" ser apontado como início do processo de independência no Rio da Prata. O Congresso de Tucumán, realizado alguns anos depois em 1816, votou a proclamação definitiva da independência das então Províncias Unidas do Rio da Prata.

${ }^{18}$ El Nacional (época segunda) foi publicado a partir de 11 de novembro de 1838, um dia após o retorno de Rivera ao poder no Uruguai. De circulação diária, o novo jornal prontamente se tornou um dos principais veículos de apoio à administração de Rivera e meio de difusão dos escritos de exilados argentinos. A partir de 15 de dezembro, a redação do periódico passou a contar com Alberdi, além dos dois editores. O novo componente participou como redator até o dia 03 de maio de 1839, quando a equipe passou a ser composta por Lamas, Juan Thompson e Félix Frias. Em outubro de 1839, o jornal sofreu nova alteração com a entrada de Rivera Indarte como principal redator, cargo que ocuparia até março de 1845.
} 
de Cuneo também para esta publicação, embora, conforme palavras de uma pesquisadora sobre o tema, a participação do italiano seja "quase invisível" ${ }^{19}$. De qualquer forma, uma leitura dos textos do periódico demonstra que houve a divulgação de idéias nacionalistas de Mazzini entre fins da década de 1830 e princípios da de 1840 .

Em pouco tempo, entretanto, os representantes da juventude rio-platense passaram a enfrentar dificuldades para publicar seus artigos no Nacional, já que suas idéias, consideradas muito radicais naqueles primeiros tempos de atuação do grupo, começaram a sofrer críticas das demais forças políticas de sustentação do governo de Rivera ${ }^{20}$. Para estes, permaneciam predominantes as visões essencialmente políticas e contratualisatas, dominantes no pensamento desde a época dos movimentos de independência, para as quais "nação" é praticamente igual a "Estado". Entre a maior parte dos círculos políticos, não havia, pois, a mesma preocupação dos “jovens de 37” em relacionar a construção nacional com questões mais amplas, como a elaboração de literatura, arte, idéias, hábitos e costumes. A maioria dos partidários do presidente oriental nem mesmo se empenhava em discutir a questão, já que suas prioridades eram a manutenção da soberania local e a luta contra a facção de Oribe. Neste sentido, enquanto a problemática nacional aparecia com destaque nos artigos de intelectuais da "Nova Geração", encontramos bem menos menções entre os escritos dos demais grupos políticos.

Com o crescente preterimento de textos de autores identificados com a Geração de 37, Cuneo igualmente perdeu espaços na imprensa de Montevidéu, dado suas aproximações com os jovens intelectuais rio-platenses. Em razão disto, em meados do ano de 1840, o periodista italiano partiu para o Rio Grande do Sul, aceitando o convite dos Farrapos para assumir a redação do periódico

\footnotetext{
${ }^{19}$ FABBRI CRESSATTI, Luce. Comienzos del periodismo italiano en el Rio de la Plata. In: Garibaldi. Publicación anual de la Asociación Cultural Garibaldina de Montevideo. Ano 7. Montevidéu: Asociación Cultural Garibaldina de Montevideo, 1992, p. 15.

${ }^{20}$ Sobre os tencionamentos entre o radicalismo do discurso da Geração de 37 e os setores liberais mais moderados, Esteban Echeverría, em sua obra Ojeada retrospectiva, relata a pouca receptividade do Código na época de sua publicação: "Ni una palabra de estímulo, de aprobación por sus nobles esfuerzos, salió para ella de entre los hombres que entonces tenían el centro del pensamiento en el Plata - Eran unos locos, unos romanticos; [...]." (ECHEVERRIA, Esteban. Obras completas. Buenos Aires: Ediciones Antonio Zamora, 1951, p. 174). O autor, deste modo, queixava-se das críticas que a elite fazia aos integrantes da Geração de 1837 durante os primeiros momentos de atuação do grupo. Suas idéias eram consideradas "loucas" e "românticas", em "desacordo" com a realidade.
} 
oficial do governo republicano, O Povo. Conforme mencionado, seu conterrâneo e amigo Luigi Rossetti tinha participado da fundação do jornal farroupilha anos antes, em $1838^{21}$.

O estado sulino vivenciava o conflito conhecido como Revolução Farroupilha. O episódio é caracterizado como o mais longo movimento de rebelião nas províncias brasileiras à época do Império, com a duração de quase uma década. Embora aspirasse à república e à autonomia regional, a Revolução Farroupilha também representou os interesses de estancieiros rio-grandenses, especialmente da região da campanha, desejosos de assumir o controle político e econômico da província, em contraposição ao projeto de Estado centralizador que o governo do Rio de Janeiro buscava impor ao país. Ainda que vinculada ao conjunto de rebeliões das províncias brasileiras no século XIX, a Revolução Farroupilha não pode deixar de ser analisada também no contexto platino, em virtude de suas conexões com os países do Prata, em meio ao tumultuado processo de formação dos Estados nacionais na região. Neste sentido, tanto os farroupilhas quanto os imperiais buscaram alianças e intercâmbios com facções políticas do outro lado da fronteira, em uma intensa circulação comercial e de idéias durante o período. As propostas de autonomia dos farroupilhas, por exemplo, estavam em sintonia com as reivindicações de diversas províncias argentinas e da República Oriental do Uruguai, em luta contra os projetos de centralização política e econômica de Buenos Aires.

Estabelecido em Piratini, então capital da República Rio-Grandense, Rossetti foi nomeado redator do periódico, conforme cartas do autor e um documento assinado por Domingos José de Almeida ${ }^{22}$, exercendo a função desde a primeira até a edição de número 47. As marcas da passagem do periodista italiano pelo jornal são notórias. Abaixo do título do periódico, inscrevia-se a

\footnotetext{
${ }^{21} \mathrm{O}$ periódico farroupilha $O$ Povo veio à luz no dia 01 de setembro de 1838 . Com o caráter de jornal oficial do governo republicano, suas edições eram publicadas, salvo alguns períodos de interrupção, às quartas-feiras e aos sábados, primeiramente em Piratini e, a partir do número 46, em Caçapava, respectivas capitais da República Rio-Grandense. Em 23 de maio de 1840, na edição de número 160, o periódico deixou de circular, após um ataque das forças imperiais que danificou a tipografia.

${ }^{22}$ Consultar cópia do documento em que Domingos José de Almeida cita Luigi Rossetti como redator de $O$ Povo em CANDIDO, Salvatore. La rivoluzione riograndense nel carteggio inedito di due giornalisti mazziniani: Luigi Rossetti e G. B. Cuneo (1837-1840). Florença: Valmartina Editore, 1973, p. 24-25.
} 
consigna mazziniana "Liberdade - Igualdade - Humanidade". Além disso, em todas as edições de $O$ Povo, consta a seguinte epígrafe: "O poder que dirige a revolução, tem que preparar os ânimos dos Cidadãos aos sentimentos de fraternidade, de modéstia, de igualdade e desinteressado e ardente amor da Pátria. Jovem Itália. Vol. V."

Mazziniano convicto, Rossetti procurou difundir o ideário de seu compatriota em artigos escritos para o periódico farroupilha, enquanto seu amigo Cuneo fazia o mesmo na imprensa de Montevidéu. Escrevendo para um grupo de republicanos, que lutavam contra o regime monárquico brasileiro, Rossetti enfatizava um aspecto do nacionalismo mazziniano: a identificação da nação com a república. Neste ponto, havia uma plena sintonia entre as idéias do italiano e dos revolucionários rio-grandenses.

Nas primeiras edições de $O$ Povo, Rossetti escreveu textos sobre a questão social, em um tom igualitário bastante radicalizado, como percebemos no artigo O Povo! O Povo!, um de seus mais eloqüentes, publicado em duas partes, nos números cinco e seis do periódico:

Eis o grito da época, eis a bandeira Republicana, que o século XIX levantou, convidando as multidões a reunir-se ao seu redor; e as multidões que gemendo desde que há memória de homens, debaixo do prezado [sic] jugo de tiranias sempre novas e sempre refinadas, tremiam no silêncio, escutaram este grito regenerador, sentiram o impulso irresistível, e, sublevada a bandeira santa, declararam guerra a tudo quanto lhes era inimigo, a tudo quanto teria o ardil de opor-se ao movimento generoso. ${ }^{23}$

Estes pobres descalços, esfarrapados que tantas vezes, vós os privilegiados do Universo, tendes postos em movimento, conseguiram nunca gozar na mais pequena proporção do bem comum no qual por tanto tinham tão grande direito de participar?[...] E a mulher, esta metade do gênero humano, a mãe de nossos filhos e a de nós mesmos, a companheira incansável de nossas desventurosas, e deleite de nossa vida, como foi tratada? Reduzida a vil escrava, a mártir da Sociedade, a ser prostituto e abjeto já não sabe distinguir a chama divina espiritual e eterna do amor que devia acender da faísca ligeira imperceptível material do prazer ao qual infimamente vós tendes apenas educada? Vós traístes assim o Povo, e vós o acusais de ingrato? ${ }^{24}$

\footnotetext{
${ }^{23}$ O Povo, n. ${ }^{\circ}$ 5, Piratini, 15/09/1838, p. 4.

${ }^{24}$ O Povo, n. ${ }^{\circ}$ 6, Piratini, 19/09/1838, p. 4.
} 
Além da defesa dos setores mais pobres e desfavorecidos da sociedade, o autor do texto fez uma clara crítica às lideranças políticas que, muitas vezes, apelam para o conjunto do povo em busca de adesões a uma revolução, mas, uma vez chegando de forma triunfante ao poder, desconsideram os apoios recebidos, deixando os mais humildes na mesma situação anterior.

Seguramente, estas palavras não agradaram muitos líderes farroupilhas, como atesta a mudança de comportamento de nosso personagem. Rossetti, neste sentido, logo "amenizou" sua linguagem e não mais encontramos referências a um vocabulário tão radicalizado nas edições posteriores de $O$ Povo.

As adaptações do ideário mazziniano na Região Platina não ficaram restritas a uma ênfase no republicanismo. Para contentar os lideres rio-grandenses, Rossetti foi obrigado a modificar algumas concepções das idéias de Mazzini, como no caso do federalismo. O fundador da Jovem Itália era partidário da unidade italiana, criticando as propostas de federalismo. Os farroupilhas, apesar de lutarem por sua independência, sempre se demonstraram favoráveis a estabelecer tênues formas de federação com outras províncias brasileiras, desde que a plena autonomia da República Rio-Grandense estivesse assegurada. Referindo-se ao federalismo, desta forma, Rossetti foi levado a alterar concepções mazzinianas em seus textos, adequando seu discurso para a realidade rio-grandense.

Ao mesmo tempo em que modificava parte de seu ideário, incorporando aspectos do discurso político local no tocante ao federalismo, o jornalista italiano buscava incutir nos farroupilhas alguns pontos do nacionalismo mazziniano, em especial o caráter internacional das lutas dos partidários da liberdade contra as tiranias em todo o mundo. Desta forma, tentou aproximar o Rio Grande do Sul das outras repúblicas do Prata, tanto defendendo esta aproximação, como fazendo circular, entre os farroupilhas, textos dos jovens intelectuais da Geração de $1837^{25}$. Estes intuitos foram explicitados nos seguinte trecho de um artigo do italiano:

\footnotetext{
${ }^{25}$ Sobre a circulação de textos dos “jovens de 37" entre os farroupilhas rio-grandenses, consultar nosso artigo: SCHEIDT, Eduardo. Idéias da "geração de 1837” na imprensa farroupilha rio-grandense. In: Estudos Leopoldenses: série História. Revista do Programa de Pós-Graduação em História da Universidade do Vale do Rio dos Sinos. São Leopoldo: v. 3, n. ${ }^{\circ}$ 1, 1999, p.67-78. Neste texto, analisamos vários textos originariamente publicados em El Nacional e El Iniciador, de Montevidéu, traduzidos e publicados no periódico O Povo. A divulgação das idéias dos intelectuais de 37 entre os farrapos rio-grandenses era um aspecto ainda não trabalhado pela historiografia da Revolução Farroupilha. Nosso estudo forneceu, neste sentido, novos elementos que apontam para um intercâmbio de idéias entre os rio-grandenses e os habitantes das Repúblicas do Prata durante a Revolução Farroupilha.
} 
A guerra que sustentamos não é uma guerra individual é a da América, é a do princípio republicano que há de vencer, e dar o último abalo ao Império. Um trono não pode aqui subsistir. - É uma mancha que todos devemos concorrer para apagá-la. A época em que as Repúblicas do Sul têm que convergir um só centro já a entrevemos, e bem depressa chegará. [...]. Para alimentarmos semelhante tendência acreditamos coisa útil oferecer a nossos leitores extratos daquelas obras, e jornais estrangeiros, que conforme os nossos princípios, possam contribuir à sua mais pronta propagação, fazendo-lhes conhecer aqueles, que merecem de preferência suas simpatias.

Começamos pela publicação do seguinte Artigo extraído do Iniciador, jornal, que se imprime em Montevidéu, redigido por um diminuto número de jovens, que honram, a si, e à sua Pátria. - Possam os jornais Rio-Grandenses seguir tão nobre exemplo! - Recomendamo-lhes aquele jornal já pela santidade do fim, já pela habilidade extraordinária, com que seus Redatores desempenham tão melindrosa tarefa. ${ }^{26}$

O artigo, ao qual Rossetti se referiu, intitulava-se Povos e governos e foi originariamente publicado no Iniciador. $\mathrm{O}$ texto, traduzido para o português por nosso personagem, foi publicado naquela mesma edição de $O$ Povo. Em edições seguintes do periódico farroupilha, Rossetti publicou outras traduções de artigos dos “jovens de 37”, cujo conteúdo expressava o ideário do grupo, além de vincular a Revolução Farroupilha aos movimentos revolucionários rio-platenses, todos eles tendo origem, segundo os textos, no "maio de 1810". Os artigos do italiano, bem como suas traduções de textos dos intelectuais da Geração de 37, foram publicados na imprensa farroupilha numa conjuntura em que os republicanos rio-grandenses procuravam acercar-se de grupos políticos dos países platinos. Neste sentido, as afinidades ideológicas entre o movimento no Rio Grande do Sul e as mobilizações nos Estados vizinhos, que Rossetti buscava difundir no periódico, vinham ao encontro dos lideres farroupilhas ${ }^{27}$. Nosso autor, ansioso para ver a realização de seu ideário na

${ }^{26}$ O Povo, n. ${ }^{\circ}$ 27, Piratini, 01/12/1838, p. 3.

${ }^{27}$ As políticas de alianças dos farroupilhas, entretanto, foram marcadas por ambigüidades. Embora os Farrapos tenham procurado, prioritariamente, estabelecer relações com o conjunto de opositores ao regime de Rosas, como o presidente do Uruguai, Frutuoso Rivera, e os governantes da província argentina de Corrientes, os republicanos rio-grandenses não deixa- 
prática, propunha unificar os Farrapos e os revolucionários rio-platenses em uma luta comum contra as "tiranias" de Rosas e do Império brasileiro. Deste modo, o jornalista italiano contribuiu para o incremento do intercâmbio de idéias entre o Rio Grande do Sul e os países vizinhos, processo iniciado desde os movimentos de independência, que se incrementou com as campanhas de Artigas, a questão da "Cisplatina" e o início da Revolução Farroupilha.

Como redator de um jornal oficial da república, Rossetti era pressionado a atender aos anseios de donos de terras e gado, uma das principais bases de apoio do movimento farroupilha. Assim, após a publicação de textos radicalizados, percebemos, em seus artigos posteriores, um tom bem mais moderado, inclusive com referências ao direito de propriedade, conforme o seguinte trecho de um de seus escritos:

Somos os primeiros a reconhecer a urgente necessidade de se garantir aos Cidadãos religiosamente o Direito de propriedade e de Liberdade em toda a sua plenitude, pois que em um Governo Democrático todos os cidadãos devem render à Liberdade um culto majestoso, como a uma Divindade; o sábio Filangieri chamou a Liberdade - a garantia de todos os Direitos do homem, e a consciência em que ele permanece, de que todos estes Direitos lhe são garantidos - assim, sendo o Direito de propriedade um desses Direitos sagrados do homem, todo aquele que o chega a violar, viola a Liberdade; e quem ataca a Divindade da Liberdade, é um ímpio, é um déspota, é um infame, é um indigno do nome de Republicano, por isto que republicano é sinônimo de homem livre, ou que rende culto à Liberdade. ${ }^{28}$

ram de procurar contatos com Rosas e Lavalleja. O “jogo duplo" nas relações externas esteve presente entre todas as facções envolvidas. Rivera, por exemplo, assumia compromissos tanto com a oposição rosista e a República Rio-Grandense quanto com o Império do Brasil, sendo que freqüentemente não os cumpria. Rosas estimulara o desencadeamento da Revolução Farroupilha, mas depois se posicionou contra a mesma e ao lado do governo brasileiro. Da mesma forma, conforme a conjuntura do momento, o Rio Grande do Sul também buscou, ora a aliança com Rosas, ora com seus opositores. Como o porto de Rio Grande sempre esteve controlado pelos imperiais, era imprescindível, para os farroupilhas, a aliança com quem estivesse no governo do Uruguai, já que eles utilizavam o porto de Montevidéu para o comércio exterior. Sobre as alianças externas à época da Revolução Farroupilha, consultar GUAZZELLI, Cesar Augusto Barcellos. O horizonte da província: a República Rio-Grandense e os caudilhos do Rio da Prata (1835-1845). Tese de doutorado. Rio de Janeiro: UFRJ, 1997.

${ }^{28}$ O Povo, n. ${ }^{\circ}$ 10, Piratini, de 03/10/1838, p. 2. 
Defesas do direito à propriedade, bem como, das garantias individuais, não são recorrentes nos textos de Mazzini. Ao contrário, ele era um ferrenho defensor da igualdade e, muitas vezes, criticava o individualismo liberal, embora não condenasse, em essência, o direito à propriedade. As crescentes pressões em atender às aspirações dos Farrapos obrigaram nosso autor a contrariar alguns pontos de suas idéias, colocando-o em uma situação desconfortável. Entre ele e setores da liderança dos republicanos rio-grandenses se estabeleceu um clima de tensão, que o conduziria a pedir sua demissão do cargo de redator do jornal.

A renúncia ao cargo não significou abandono do movimento, já que o italiano passou a contribuir de outra forma, acompanhando os farroupilhas em campanhas militares. Não disposto a transigir de suas convicções políticas, preferiu a função de soldado à de "jornalista controlado". Uma das campanhas mais importantes, da qual participou, foi a tomada de Laguna, na província vizinha de Santa Catarina, em julho de 1839. Após esse triunfo, foi fundada a "República Catarinense", que perduraria somente por poucos meses. De lá, Rossetti continuou escrevendo textos e manifestos, muitos publicados em edições posteriores de $O$ Povo.

Conforme anteriormente mencionado, os farroupilhas contrataram seu amigo e colega Cuneo para o cargo de redator do jornal, em maio de 1840. Assim, ele se tornou responsável pelas últimas edições de $O$ Povo. Nos anos anteriores, enquanto estivera radicado em Montevidéu, Cuneo tinha mantido contatos com Rossetti, inclusive enviando-lhe textos que foram publicados no jornal rio-grandense.

Em seus textos para $O$ Povo, Cuneo deu continuidade à estratégia de aplicar o ideário mazziniano, adaptando-o ao contexto político local. Nos meses em que esteve no Rio Grande do Sul, deparou-se com um momento crítico para os farroupilhas. Ao contrário dos anos de 1838 e 1839, de máxima expansão das forças revolucionárias, em 1840, os Farrapos começaram a sofrer os revezes da contra-ofensiva dos imperiais. Nosso autor, assim, escrevia com o intuito de encorajar os farroupilhas a continuarem a luta, não se deixando abater pelas recentes derrotas.

Devido a um ataque dos legalistas, a imprensa farroupilha deixou de circular no final de maio de 1840 e Cuneo, que não era propenso a atividades militares, retornou para Montevidéu em agosto do mesmo ano, onde passaria a trabalhar pela publicação de um jornal em língua italiana. Rossetti, que continuou acompanhando o exército dos farroupilhas, veio a falecer a 24 de novembro de 1840 , próximo a Setembrina (atual Viamão), em um ataque dos imperiais no momento em que o último cerco a Porto Alegre estava sendo levantado. 
Em abril de 1841, um ano após seu retorno a Montevidéu, Cuneo distribuiu um prospecto anunciando o aparecimento de um futuro semanário, que iria se chamar L'italiano ${ }^{29}$, homônimo a um periódico que se imprimira em Marselha entre 1832 e 1834, sob a direção de Mazzini. Diferente do período anterior, em que Cuneo dirigia-se a grupos políticos locais, seja aos "jovens de 37" ou aos farroupilhas, escrevendo como se fosse um de seus integrantes, neste periódico em italiano, ele voltou-se para seus compatriotas radicados em Montevidéu, publicando textos e artigos em seu próprio nome e em sua língua nativa. Desta forma, utilizou a pena para divulgar seu nacionalismo mazziniano “original”, inclusive radicalizando-o, especialmente na questão do igualitarismo e dos "deveres do homem", conforme o seguinte trecho de um de seus artigos:

Colla teoria dei diriti possiano insorgere e rovesciare gli ostacoli; ma non fondare forte e durevole l'armonia di tutti gli elementi che compongono la Nazione. Colla teoria della felicità, del benessere dato per aggetto primo alla vita, noi formerono uomini egoisti, adoratori della materia, che porteranno le vecchie passioni nell'ordine nuovo e lo corromperanno pochi mesi dopo. Si tratta dunque di trovare un principio educatore superiore a siffatta teoria che guide gli uomini al meglio, [...], che li vincoli ai loro fratelli senza farli dipendenti dall'idea d'un solo o dalla forza di tutti. E questo principio è il DOVERE. Bisogna convincere gli uomini ch'essi, figli d'un solo Dio, hanno ad essere qui in terra esecutori d'una sola Lege - che ognuono d'essi, deve vivere, non per se, ma per gli altri - che lo scopo della loro vita non è quello d'essere più o meno felici, ma di rendere se stessi e gli altri migliori - che il combattere l'ingiustizia e l'errore a benefizio dei loro fratelli, e dovunque si trova, è non solamente diritto, ma dovere: dovere da non negligersi senza colpa - dovere di tutta la vita. ${ }^{30}$

\footnotetext{
${ }^{29}$ A publicação de Cuneo foi pela primeira vez impressa no dia 22 de maio de 1841 . Saía uma vez por semana, aos sábados e teve duas séries. A primeira, perfazendo oito edições e de distribuição gratuita, circulou até o dia 10 de julho. A segunda fase iniciou com a edição de número nove, em 04 de junho de 1842, vindo a encerrar-se com o número 23, em 10 de setembro do mesmo ano. Nesta segunda fase, as edições do jornal passaram a ser vendidas.

${ }^{30}$ L'Italiano, n. $^{\circ}$ 18, Montevidéu, 06/08/1842, p. 3-4. Tradução da citação: “Com a teoria dos direitos, podemos nos insurgir e derrubar os obstáculos; mas não fundar forte e duradoura a harmonia de todos os elementos que compõem a Nação. Com a teoria da felicidade, do bem-estar, dada como primeiro destaque à vida, nós formamos homens egoístas,
} 
Dois anos depois, nosso autor editou um novo periódico em sua língua natal, denominado Il Legionario Italiano. Igualmente como seu predecessor, a publicação objetivava divulgar o ideário mazziniano entre os imigrados na cidade, acrescentando-se a tarefa de alentar a luta dos legionários contra as forças de Oribe e Rosas. Desde 1843, a cidade de Montevidéu encontrava-se sitiada pelo exército de Oribe e Rosas. O cerco duraria até 1851. A cidade não sucumbiu devido ao apoio das esquadras anglo-francesas, que garantiram o abastecimento; na época do cerco, se mobilizou para a defesa, inclusive com adesão das populações estrangeiras lá residentes. Garibaldi foi o responsável pela organização da "Legião Italiana" e o segundo periódico em língua italiana de Cuneo dirigia-se, especialmente, àqueles legionários.

Desta forma, um dos objetivos da publicação era convencer política e ideologicamente os imigrados italianos a se engajarem na luta pela defesa da cidade sitiada. O periódico também se destacou pela sua violenta oposição ao regime rosista. Ao responder a um artigo da Gaceta Mercantil de Buenos Aires, que teria retratado a Jovem Itália como uma "sociedade sediciosa e feroz", Cuneo utilizou o mesmo tom:

[...] il governo di Buenos Ayres [é] assoluto e tirannico in tutti i suoi alti persegue a morte ne suoi domini ogni idea di libertà, e di progresso; e quindi la Giovine Italia, le di cui dottrine democratiche abbracciate dala Giovine Europa incominciano a dare seri timori alle corti europee, onde cattivarsene la simpatia, e il favore nella guerra scellerata in cui Rosas ha involto questi infelici paesi.

[...] E Rosas, il monstrum horrendum, il flagello che da 14 anni desola la Repubblica Argentina; che ha fatto della populosa cità di Buenos Ayres [...] una spaventosa caverna di masnadieri e d'infamie; che per sostenere il di lui sistema d'usurpazioni, e di sterminio ha mosso guerra a quanto di

adoradores da matéria, que portam as velhas paixões na nova ordem e corrompem-na poucos meses depois. Trata-se, portanto, de encontrar um princípio educador superior à semelhante teoria, que conduza os homens para o melhor, [...], que os vincule a seus irmãos sem os fazer dependentes da idéia de um só ou da força de todos. E este princípio é o DEVER. É necessário convencer os homens de que eles, filhos de um único Deus, devem ser quem executa na terra uma Lei única - que cada um deles deve viver, não para si, mas para os outros - que o propósito de suas vidas não é o de serem mais ou menos felizes, mas de se entregarem melhor a si mesmos e aos outros - que o combate à injustiça e ao erro em benefício de seus irmãos, onde quer que se encontrem, é, não somente um direito, mas um dever: dever de não se negligenciar sem culpa - dever de toda a vida." 
virtuoso e d'onesto existe nella Repubblica Argentina; che ha distrutto o convertido in suo pro le più belle instituzioni republicane $(. ..) .^{31}$

Para melhor convencer seus conterrâneos a engajarem-se na luta contra Rosas e Oribe, Cuneo retratava o governador de Buenos Aires com uma linguagem bastante semelhante à de seus inimigos locais. Dessa forma, para o autor, urgia a derrubada do "tirano", "usurpador do poder", "destruidor da República Argentina". O sítio de Montevidéu acirrou enormemente os ânimos, sendo praticamente impossível esquivar-se de posicionamento por uma das facções em luta. O italiano manteve-se ao lado de quem lhe dava exílio e procurou arrematar ideologicamente seus compatriotas, através dos artigos de seu periódico.

O Legionario, entretanto, teve vida bem mais efêmera do que L'Italiano. Publicaram-se apenas três edições em 27 de outubro, 11 de novembro e 26 de dezembro de 1844 e uma posterior no ano de 1846. Em princípios de 1848, chegaram notícias dos movimentos revolucionários que irrompiam em várias partes da Europa, inclusive em territórios italianos, onde a unidade do país era novamente colocada na ordem do dia. Muitos italianos, exilados no exterior, voltaram a sua terra natal para se engajarem nos movimentos. Foi o caso de Cuneo, que, ao partir rumo à Europa, encerrou o primeiro momento da nação mazziniana na Região Platina.

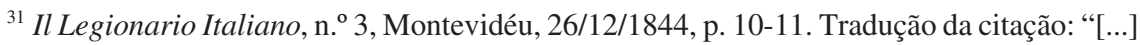
o governo de Buenos Aires [é] absoluto e tirânico em tudo; do seu topo persegue, até a morte, em todos seus domínios, toda idéia de liberdade e de progresso; e, consequentemente, persegue a Jovem Itália, cujas doutrinas democráticas adotadas pela Jovem Europa, que começavam a causar sérios temores às cortes européias, a fim de atrair simpatia e ajuda nesta guerra perversa, na qual Rosas envolveu estes países infelizes. [...] E Rosas, o monstrum horrendum, o chicote que há 14 anos desola a República Argentina, que fez da populosa cidade de Buenos Aires, [...], uma caverna assustadora de bandoleiros e infames, que para sustentar seu sistema de usurpações e extermínios moveu guerra contra tudo de virtuoso e honesto existente na República Argentina, que destruiu, ou converteu para seu interesse, as mais belas instituições republicanas; [...]." 


\section{III}

Cuneo participou ativamente das revoluções de $1848-49^{32}$ na Itália, inclusive sendo eleito deputado para o parlamento piemontês. Com a derrota dos movimentos e a restauração de governos reacionários, nosso autor foi obrigado a novamente tomar o rumo do exílio, elegendo, uma vez mais, a América como local de desterro. Após uma rápida passagem por Montevidéu, ele fixou residência em Buenos Aires, onde exerceu o ofício de jornalista após a queda de Rosas, entre os anos de 1853 e 1860, até seu retorno definitivo à Itália. Nesta fase, atuou tanto na imprensa local como em um novo periódico em língua italiana de sua responsabilidade.

O regime rosista tinha caído após a derrota - frente a uma aliança entre Justo José Urquiza, governador de Entre Rios, com os governos do Uruguai e do Brasil - das forças ligadas ao governo, na Batalha de Caseros, a 03 de fevereiro de 1852. O novo regime convocou uma constituinte para organizar politicamente o país. Logo, porém, movimentos de oposição a Urquiza intensificaram-se em Buenos Aires, onde a maior parte da população não aceitava submeter-se ao poder de outras províncias. Em 11 de setembro, irrompeu um movimento revolucionário e autonomista, obrigando o vencedor de Caseros a trasladar seu governo para a cidade de Paraná, província de Entre Rios. Lá, foi promulgada a Constituição em 1853, que estabeleceu a "Confederação Argentina", formada por treze províncias, e elegeu Urquiza para o cargo de presidente da república. Buenos Aires, que ficou de fora da federação, elaborou uma própria Constituição no ano seguinte, ratificando a condição da província como Estado independente. A existência de dois Estados independentes prevaleceu até 1859, quando Buenos Aires finalmente incorporou-se à confederação. Em 1862, após a vitória dos bonaerenses sobre os federalistas na Batalha

\footnotetext{
${ }^{32}$ Os movimentos revolucionários italianos de 1848 e 1849 inserem-se no conjunto de mobilizações, revoltas e revoluções ocorridas em boa parte dos países europeus em 1848. Exemplo único de movimentos praticamente simultâneos, surgidos espontaneamente entre as camadas populares, aquelas revoluções ficaram conhecidas como "Primavera dos Povos". Em oposição aos regimes autoritários da "Santa Aliança", os revoltosos de 48 mobilizaram-se não somente em torno de idéias liberais, mas também socialistas, tendo sido a primeira vez em que muitos operários tiveram uma participação política em torno de suas reivindicações específicas. Assim como surgiram rapidamente em vários cantos da Europa, os movimentos foram sistematicamente sufocados, num curto prazo, na grande maioria dos países do continente.
} 
de Pavón, Bartolomé Mitre foi eleito o primeiro presidente constitucional para todo o território da Argentina.

Foi, pois, numa província convertida em Estado independente, que Cuneo atuou como jornalista durante a década de 1850. Embora em luta contra os federalistas liderados por Urquiza, Buenos Aires estava dividida em dois grupos políticos rivais. De um lado, havia os "autonomistas", desejosos de uma separação total da província, entre os quais se destacava Valentín Alsina. Por outro lado, sob a liderança de Mitre, havia os que viam a secessão como um estágio provisório, pregando o estabelecimento de uma nação, unificada e encabeçada por Buenos Aires, para o conjunto do território argentino.

Cuneo passou a contribuir para o periódico liberal portenho La Tribuna ${ }^{33}$, que tinha conquistado, em pouco tempo, um grande espaço, constituindo-se num dos principais veículos da imprensa durante o período. As idéias defendidas pelo jornal expressavam um novo patamar no debate sobre a questão nacional na era pós-Caseros. Uma das preocupações centrais era a organização do Estado, questão ainda não resolvida, que continuava suscitando disputas políticas e militares. Entretanto, para setores cada vez mais numerosos das elites urbanas de Buenos Aires, a nação deixava de ser apenas a criação de um Estado, significado predominante na época da independência, passando a se associar a questões mais amplas, como a do tipo de sociedade que se desejava construir. Neste sentido, a fundação de uma nação começou a ser identificada com o "progresso", o desenvolvimento, a "civilização", bem como a luta contra os resquícios da "barbárie", denominação que as elites urbanas davam à vida rural, aos "caudilhos" e às populações indígenas.

Em meio a essas discussões, circulavam distintos projetos nacionais. Um dos que mais conquistou adeptos foi o de Juan Bautista Alberdi. Destacado autor da Geração de 1837, radical defensor da "revolução americana" nos primeiros tempos de atuação do grupo, Alberdi tinha se tornado bem mais moderado desde os últimos anos da era Rosas. De intransigente opositor ao governador bonaerense, passou a elogiar sua centralização política, que teria unificado "de fato" o país. Para o intelectual argentino, seria preciso institucionalizar este poder após a queda de Rosas, daí a publicação de seu famoso livro Bases

${ }^{33}$ O periódico começou a circular em 07 de agosto de 1853. Com periodicidade diária, La Tribuna era redigida pelos irmãos Hector e Mariano Varela. 
y punctos de partida para la organización política de la República Argentina, que inspirou os constituintes de 1853 . O projeto alberdino concedia ampla liberdade econômica para as elites, ao mesmo tempo em que restringia a liberdade política em nome da "ordem" e do progresso. Alberdi defendia o modelo exportador como fundamento do desenvolvimento da "nação" e para inserção do país no mercado internacional. Seria preciso passar pela etapa da "república possível”, dando plena liberdade às elites, enquanto os demais setores da sociedade teriam que ser controlados através de uma participação política restringida. Alberdi também propunha a imigração em massa de europeus como forma não somente de ocupar, mas principalmente de "civilizar" a "nação". Segundo esta perspectiva, a vinda de grandes contingentes de pessoas "cultas" da Europa seria a maneira de derrotar os "bárbaros" do continente americano.

Um contraponto ao projeto de Alberdi encontrava-se nas idéias defendidas por Domingo Faustino Sarmiento. Assim como aquele, este igualmente se preocupava com o triunfo da "civilização" sobre a "barbárie". Porém, ao contrário de Alberdi, Sarmiento não confiava nas elites nem no modelo de grandes propriedades de terra para a conquista da nação almejada. Também não via nos países europeus, considerados "aristocráticos" e "retrógrados", especialmente após as repressões aos movimentos de 1848, um exemplo a ser seguido pelos argentinos. Tendo como modelo os Estados Unidos, propunha o incentivo às pequenas propriedades de terras, à integração do mercado nacional e à educação em massa da população como fundamentos para se chegar ao progresso.

Embora com diferenças importantes, ambos os projetos para a "nação argentina" estavam centrados na preocupação de "civilizar" o país e vencer a "barbárie". Com estes propósitos, estabeleceram-se políticas de repressão às populações rurais, tidas como "massa de manobra dos caudilhos", e aos indígenas, retratados como um "entrave à civilização". Além de reprimidos, estes setores da sociedade ficaram excluídos de qualquer tipo de cidadania. Eram tempos da "nação da civilização versus barbárie". As novas idéias acerca da construção da nação eram amplamente difundidas e debatidas nos inúmeros espaços de sociabilidade política que floresceram na Buenos Aires pós-rosista, tais como cafés, clubes literários, partidos políticos e periódicos, que se multiplicaram após o restabelecimento da liberdade de imprensa.

Em suas contribuições para a Tribuna, o jornalista italiano elogiava, com freqüência, a política dos liberais portenhos. Via com bastante otimismo as possibilidades da construção da "nação", não apenas na Argentina, mas na 
América como um todo. Posicionando-se ao lado dos liberais portenhos, Cuneo criticava Urquiza e o governo da confederação, retratados como "tiranos" e "caudilhos", à semelhança com o deposto regime rosista. Além da defesa da política liberal, o jornalista italiano se utilizou da pena para dar continuidade à difusão de seu ideário mazziniano, conforme o exemplo abaixo de um de seus artigos:

Hubo un tiempo en que el egoismo nacional, y el odio hacia los pueblos estrangeros, parecieron cosntituir el verdadero amor de la patria. [...]. El sentimiento cristiano, que ensenaba que todos los hombres eran hermanos e hijos de un mismo padre, luchaba todavia contra las falsas doctrinas heredadas del paganismo, [...].

Todos sienten que vivimos los unos para los otros: el individuo para la familia, la familia para la patria, la patria para la humanidad. Es una escala ascendiente, donde todas las fuerzas sociales van a reunirse para realizar el designo que la Providencia nos ha marcado. ${ }^{34}$

Os princípios mazzinianos de humanidade, luta contra o egoísmo individualista, bem como conteúdo profundamente messiânico e religioso do ideário político, continuam norteando o pensamento de Cuneo. Entretanto, percebemos que suas idéias estavam mais atenuadas, pois há uma ausência, no conjunto de seus textos e artigos, da defesa da revolução e principalmente da igualdade social, tão cara aos seguidores de Mazzini em tempos anteriores. Em substituição à igualdade radical, a democracia passou a ser a tônica dos escritos do autor no período.

Com relação à democracia, Cuneo comparava a situação de Buenos Aires (e da América em geral) com a da Europa. No texto Democracia y despotismo, por exemplo, o autor considerou que o continente americano estaria bem mais adiantado do que o europeu no que ser refere à democracia, apontada como base de qualquer projeto nacional:

La América, inmenso campo reservado a ver realizado en su seno los más arduos esperimentos de la democracia; cuya bandera flamea de uno a otro hemisferio de nuestro continente; la América no puede dejar, sin faltar al princípio que es la base de su existencia, de hacer eco a la voce

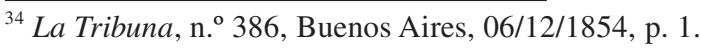


de los pueblos que pelean por el triunfo de la causa que sostenemos, y apoyarla con su simpatia y su adhesión franca y decidida.

La Europa gime hoy casi toda bajo el peso de la tirania - la voz de los hombres libres está condenada al silencio; y la insolencia de los dominadores insulta a su antojo a los desventurados de los oprimidos. La joven y libre América, puesto que no puede hacer otra cosa, no permitirá, al menos que un solo lamento del que sufre las consecuencias de la injusticia, ni las acciones de los que las hacen sufrir, pasen inapercibidas, y sin que acompañe al primero con una palabra de afecto y un incitamento en preservar, y a los segundos con su reprobación y su anatema. ${ }^{35}$

Certamente o último período em que esteve na Europa, durante o qual tinha vivenciado a mais uma derrota dos movimentos nacionalistas italianos, deixou marcas profundas em Cuneo, expressas no pessimismo com o qual o autor tratava sua terra natal. Aos seus olhos, a Buenos Aires governada por políticos liberais, com pleno funcionamento de instituições republicanas, estaria numa situação bem mais promissora do que o conjunto das terras italianas, ainda divididas e sob jugo de governos despóticos ou de países estrangeiros, mesmo após várias intentos revolucionários que se frustraram, especialmente os movimentos de 1848 .

Em 1856, nosso personagem voltou a escrever em sua língua nativa. Em 21 de janeiro, veio à luz o primeiro número de La Legione A gricola $^{36}$, periódico dirigido à recém fundada colônia italiana "Nova Roma", nas cercanias de Bahia Blanca. A denominada "Nova Roma" consistia em uma colônia agrícola e militar, cujos propósitos eram assegurar a ocupação territorial da região por parte do governo de Buenos Aires e a conseqüente expulsão dos indígenas.

Este periódico foi bastante distinto dos anteriores jornais italianos dirigidos por Cuneo. Assim como nos textos para a Tribuna, os artigos publicados no Legione Agricola caracterizavam-se pela defesa das concepções políticas de setores da elite portenha, em especial o projeto de nação da "civilização" versus "barbárie", segundo o qual a questão nacional ultrapassa a organização

\footnotetext{
${ }^{35}$ Idem, Ibidem, p. 1.

${ }^{36} \mathrm{O}$ periódico era editado na tipografia da Tribuna, em Buenos Aires. Sem periodicidade fixa, La Legione Agrícola circulou de 21 de janeiro a 24 de setembro de 1856, perfazendo um total de 17 edições.
} 
de um Estado unificado, associando-se ao projeto de desenvolvimento econômico, ocupação territorial com vinda de imigrantes europeus, propriedade privada, urbanização, bem como luta contra os resquícios da "barbárie", entendida, sob esta concepção, como a política dos federalistas, o fenômeno do "caudilhismo" e as populações indígenas.

Porém, nos artigos publicados no periódico, desapareceu, quase por completo, o nacionalismo mazziniano, em meio a uma eloqüente defesa do ideário liberal de setores da elite portenha, enfatizando-se a luta contra a "barbárie", no caso, as populações indígenas. No que se referia a estas, a irmandade entre os povos parece ter sido "esquecida”, uma vez que os índios estavam excluídos do projeto nacional propagado pelo Legione. Nesta questão, nos deparamos com um vocabulário bastante agressivo contra os indígenas, o que, em se tratando de um autor mazziniano, não deixa de ser surpreendente. Era uma constante, entre seus artigos, trechos como o seguinte:

Ma i danni causati dagli indii contro le proprietà private, e le persone di que disporni sono di grave importanza; [...].

Pace che non può essere durevole per la nota perfidia dei selvaggi, e che d'altronde non può essere accettata dal governo di Buenos Aires, che deve ad ogni costo adoperarsi onde togliersi dinanzi questa perpetua minaccia delle invasioni, che tanti danni arrecano agli stabilimenti rurali, alle vite dagli abitanti di quella parte della campagna e allo spirito d'intrapresa. ${ }^{37}$

Para o autor, seria necessário o extermínio de tais populações, retratadas como um "entrave" ao desenvolvimento nacional além de colocadas no papel de "agressores" e "invasores", "esquecendo-se" que eram os colonizadores que estavam invadindo um território até há pouco tempo livre para os indígenas.

${ }^{37}$ La Legione A gricola, n. ${ }^{\circ}$ 3, Buenos Aires, 26/02/1856, p. 4. Tradução da citação: "Mas os danos causados pelos índios contra as propriedades privadas e as pessoas que as dispõem são de grave importância; [...]. Paz que não pode ser duradoura devido à conhecida perfídia dos selvagens e que, por outro lado, não pode ser aceita pelo governo de Buenos Aires, que deve, a todo custo, esforçar-se a fim de se livrar desta ameaça perpétua de invasões, que tantos danos causam aos estabelecimentos rurais, às vidas dos habitantes daquela parte da campanha e ao espírito empreendedor." 
Além do tom agressivo contra os índios, retratados como "pérfidos" e "traiçoeiros", o autor enfatizava o fato de eles supostamente atentarem contra a propriedade e o "espírito empreendedor". Quem desconhecesse os escritos da época do exílio anterior de Cuneo e lesse somente os artigos do Legione, provavelmente os suporia escritos por um autor identificado com o liberalismo, ou até, por um conservador.

O mais surpreendente é que, neste periódico, o periodista italiano não escrevia para os liberais portenhos, e sim se dirigia a seus compatriotas radicados no país. Neste sentido, houve uma acentuada mudança de postura em relação à fase anterior, na qual o autor procurava difundir o nacionalismo mazziniano entre os italianos residentes na América. Neste outro momento, Cuneo claramente objetivou dar sustentação ideológica ao projeto dos governantes de Buenos Aires de utilizar os imigrantes para ocupação territorial das áreas disputadas com os indígenas. Os propósitos dos artigos escritos por nosso personagem, neste sentido, eram de convencer seus compatriotas a aderir ao projeto colonizador de tomar posse das terras mais ao sul e exterminar os índios que continuavam resistindo.

Com o término da circulação do Legione Agrícola, Cuneo não voltaria mais a publicar outro periódico em italiano durante seus últimos anos de exílio em Buenos Aires. Continuou contribuindo para a Tribuna até novembro de 1860, quando partiu definitivamente para a Itália, seduzido pelas notícias oriundas da Europa sobre o novo movimento pela unificação italiana, que finalmente obteria êxito. Em seu país natal, Cuneo estabeleceu contatos com Garibaldi e foi nomeado, em 1862, cônsul geral do governo argentino em Gênova, não aceitando o cargo. Nos anos seguintes, viveu em Florença e Gênova, onde integrou a "Sociedade Emancipatória", que tinha como finalidade a libertação de Roma e Veneza, que haviam ficado de fora da unificação conquistada em 1860. No ano de 1866, Cuneo acompanhou Garibaldi na "Campanha do Trentino". Nos últimos anos de sua vida, foi nomeado, pelo governo argentino, "agente geral da emigração", cargo que ocupou até sua morte em Florença em dezembro de 1875.

\section{IV}

Tratamos, ao longo deste artigo, de um uma análise da atuação, na imprensa da Região Platina, de dois periodistas italianos refugiados, em meados do século XIX. Quando aportaram na América, Cuneo e Rossetti, já carregando a experiência de militância em sociedades secretas e lutas clandestinas con- 
tra regimes arbitrários, vincularam-se com setores opositores ao regime de Rosas, em meio à conturbada conjuntura de construção dos Estados nacionais na região. Românticos e revolucionários, seu ideário os fez identificar a luta na América com a da Itália. Neste sentido, as batalhas travadas contra o despotismo da "Santa Aliança" seriam as mesmas que se realizavam contra os governos autoritários de Rosas e do Império do Brasil. Em ambos os continentes, aspirava-se à conquista de nações livres e soberanas, no interior das quais se asseguraria ampla liberdade e igualdade entre as pessoas.

Durante o período analisado, percebemos que os jornalistas italianos contribuíram para os debates sobre a construção das nações na Região Platina, difundindo as idéias radicais e igualitárias de Mazzini. Cuneo e Rossetti também estimularam a circulação de idéias entre o Rio Grande do Sul e seus vizinhos platinos. Cruzando fronteiras, eles promoveram o incremento de intercâmbios e alianças entre os farroupilhas e os grupos políticos opositores ao regime rosista, propondo a união dos que eram considerados autênticos republicanos e democratas, a exemplo dos mazzinianos, contra os governos de Buenos Aires e do Rio de Janeiro, apontados como análogos à "Santa Aliança".

Ao longo do primeiro momento de divulgação da "nação mazziniana" na Região Platina, nossos personagens aproximaram-se dos intelectuais da Geração de 1837, em Montevidéu, e dos farroupilhas, na então República Rio-Grandense. Cuneo e Rossetti procuraram adequar suas idéias de nação ao ideário dos grupos locais, buscando convertê-los ao nacionalismo mazziniano. Durante seu segundo exílio na América, Cuneo, desta vez em Buenos Aires, comportouse de modo mais pragmático e menos radical, oscilando entre um mazzinismo mais "atenuado" e a defesa da concepção de "nação da civilização versus barbárie", que ganhava força entre políticos liberais portenhos. Sustentou, inclusive, o projeto dos governantes de Buenos Aires de estabelecer uma colônia agrícola-militar, com a utilização de imigrantes italianos, para assegurar a ocupação de territórios arrebatados dos indígenas.

Neste sentido, percebemos que Cuneo e Rossetti modificaram e "ajustaram" suas idéias ao contexto local, ao longo de suas trajetórias em diferentes espaços da Região Platina. Seu ideário original confrontou-se com idéias e práticas locais, estabelecendo-se uma "zona de contato". Ao se radicarem na América como refugiados políticos, interagiram com grupos locais, "confrontando" o ideário destes com os seus. Desta forma, procedeu-se uma "transculturação" de idéias, uma vez que os jornalistas italianos se "americanizaram", modifica- 
ram suas concepções originais, incorporando parte do ideário de grupos políticos com os quais travam relações, mesclando-o com seus pensamentos trazidos da Itália. Esta transculturação foi mais acentuada no segundo momento do nacionalismo mazziniano na Região Platina, quando Cuneo aderiu, quase que plenamente, às idéias e concepções de nação dos círculos intelectuais portenhos. Percebemos, no autor, um abandono do conteúdo igualitário e radical de suas idéias.

O que teria levado Cuneo a mudar tão radicalmente seu discurso? Uma explicação para a mudança talvez seja uma crescente decepção, ao longo dos anos, com a falta de receptividade das idéias mais radicais, que praticamente não encontraram eco nem na Europa nem na América. O ideário mazziniano conquistou a adesão somente de restritos grupos minoritários, enfrentando a forte oposição de outras facções políticas e a indiferença da maior parte da população. Além disso, os movimentos revolucionários, nos quais o italiano se engajou, foram sistematicamente derrotados em ambos os continentes. De um árduo militante mazziniano, profundamente envolvido com suas convicções nacionalistas radicalizadas, Cuneo tornou-se um intelectual mais pragmático e resignado ao longo do tempo. Outro fator que deve ser levado em conta é que o italiano reencontrou, em seu novo exílio na Região Platina, seus amigos da Geração de 37 também modificados em relação ao período anterior. Do igualitarismo radical, muitos aderiam a um liberalismo mais moderado, como no caso de Alberdi, que passou a defender a "república possível", apregoando a necessidade de conceder liberdade econômica a grandes proprietários, enquanto restringia os direitos políticos da maioria da população.

Acreditamos que sua resignação levou Cuneo a ver no projeto da "civilização" versus "barbárie" o mais "progressista" entre os plausíveis de se realizar na época. Neste sentido, ao elogiar seguidamente o governo de Buenos Aires, comparando-o com a situação européia, pensamos que o autor foi sincero ao descrever a "superioridade" do republicanismo americano em relação ao despotismo do qual a Itália não conseguia se desvencilhar. O florescimento de inúmeras associações políticas e culturais em Buenos Aires, além de um grande número de periódicos com o restabelecimento da liberdade de imprensa, são, de fato, elementos que contrastavam com a situação dos territórios italianos, onde recrudesciam o autoritarismo e as perseguições a opositores, após as derrotas dos movimentos de 1848 e 1849.

Embora tenham chegado à América com o intuito de difundir o ideário mazziniano no continente, Cuneo e Rossetti não deixaram de vivenciar um 
processo inverso, ou seja, de incorporar idéias e concepções de grupos políticos da Região Platina, fruto do "confronto" entre ideários em uma "zona de contato". Neste sentido, refutamos as teses que designam a América Latina como mera "importadora" de idéias, ainda recorrentes em boa parte da historiografia. Pensamos, ao contrário, que houve sim transculturação e produção de ideários na Região Platina. Mesmo que se tenha recebido idéias de fora, estas sempre passaram por um ativo processo de seleção e adaptação, em virtude das especificidades do contexto histórico local.

\section{Referências bibliográficas:}

\section{1- Fontes (jornais):}

El Iniciador - Montevidéu, 1838-1839. Edição fac-similada da Academia Nacional de la Historia, Buenos Aires, 1941. (consultado na Biblioteca do Instituto de Historia Argentina y Americana Dr. Emilio Ravignani, Buenos Aires)

L'Italiano - Montevidéu, 1841-1842. (consultado na Biblioteca do Colégio Nacional de Buenos Aires)

Il Legionario Italiano - Montevidéu, 1844-1846. (consultado na Biblioteca Pública da Universidade Nacional de La Plata)

La Legione Agricola - Buenos Aires, 1856. (consultado na Biblioteca Nacional de Buenos Aires)

El Nacional (época Segunda) - Montevidéu, 1838-1843. (consultado no Museu Mitre, Buenos Aires)

O Povo - Piratini / Caçapava, 1838-1840. Edição fac-similada da Livraria do Globo, Porto Alegre, 1930. (consultado na Biblioteca Central da PUCRS, Porto Alegre) La Tribuna-Buenos Aires, 1853-1860. (consultado no Museu Mitre, Buenos Aires)

\section{2- Bibliografia:}

ALBERDI, Juan Bautista. Escritos póstumos. Tomo XIII: miscelenia, propaganda revolucionaria. Buenos Aires: Imprenta Juan Bautista Alberdi, 1900.

BETHELL, Leslie. (org.). História da América Latina. Vol. 3: da Independência até 1870. São Paulo/Brasília: Edusp/Imprensa Oficial/Funag, 2001. 
CANDIDO, Salvatore. La emigración política italiana a la América latina: (18201870). In: KONETZKE, Richard e KELLENBENZ, Hermann (orgs.). Jahrbuch für Geschichte: von Staat, Wirtschaft und Gesellschaft Lateinamerikas. Band 13. Sonderdruck: Böhlau Velvag, 1976, p. 216-238.

La pubblicistica mazziniana in Brasile e nei paesi rioplatensi nel primo ottocento. In: Bolletino della Domus Mazziniana. Pisa: 1995, n. ${ }^{\circ}$ 1, p. 11-54.

La rivoluzione riograndense nel carteggio inedito di due giornalisti mazziniani: Luigi Rossetti e G. B. Cuneo (1837-1840). Florença: Valmartina Editore, 1973.

CHIARAMONTE, José Carlos. Ciudades, provincias, Estados: orígenes de la Nación Argentina (1800-1846). Buenos Aires: Ariel, 1997.

Metamorfose do conceito de nação durante os séculos XVII e XVIII. In: JANCSÓ, István. (org.). Brasil: formação do estado e da nação. São Paulo/ Ijuí: Hucitec/Unijuí, 2003, p. 61-91.

El mito de los origenes en la historiografia latinoamericana. Cuadernos del Instituto Ravignani, n. 2. Buenos Aires: Instituto de Historia Argentina y Americana Dr. Emilio Ravignani, 1991.

El problema de los orígenes de los estados hispanoamericanos en la historiografia reciente y el caso del Rio de la Plata. In: Anos 90. Revista do curso de pós-graduação em História. Porto Alegre: UFRGS, v. 1, n. 1, 1993, p. 49-83.

ECHEVERRIA, Esteban. Obras completas. Buenos Aires: Ediciones Antonio Zamora, 1951.

FABBRI CRESSATTI, Luce. Comienzos del periodismo italiano en el Rio de la Plata. In: Garibaldi. Publicación anual de la Asociación Cultural Garibaldina de Montevideo. Ano 7. Montevidéu: Asociación Cultural Garibaldina de Montevideo, 1992, p. 7-23.

Italianos en Brasil y en el Plata en tiempos de Garibaldi. In: Garibaldi. Publicación anual de la Asociación Cultural Garibaldina de Montevideo. Ano 3. Montevidéu: Asociación Cultural Garibaldina de Montevideo, 1988, p. 85-114.

FLORES, Moacyr. Modelo político dos farrapos. $3^{\text {a }}$ ed. Porto Alegre: Mercado Aberto, 1985.

GUAZZELLI, Cesar Augusto Barcellos. O horizonte da província: a República Rio-Grandense e os caudilhos do Rio da Prata (1835-1845). Tese de doutorado. Rio de Janeiro: UFRJ, 1997. 
GONZÁLEZ BERNALDO, Pilar. Civilidad y política en los orígenes de la Nación Argentina: las sociabilidades en Buenos Aires (1829-1862). Buenos Aires: Fondo de Cultura Económica, 2001.

. La "identidad nacional" en el Río de la Plata post-colonial: continuidades y rupturas com el antiguo régimen. In: Anuario del IEHS "Prof. Juan C. Grosso”, n. 12. Tandil: Universidad Nacional del Centro de la Provincia de Buenos Aires, 1997, p. 109- 122.

GOROSTEGUI DE TORRES, Haydée. La organización nacional: historia argentina, t. 4. Buenos Aires: Paidós, 2000.

HALPERIN DONGHI, Tulio. De la revolución de independencia a la confederación rosista: historia argentina, t. 3. $4^{\text {a }}$ ed. Buenos Aires: Paidós, 1993.

LEITMAN, Spencer. Raízes sócio-econômicas da guerra dos farrapos. Rio de Janeiro: Graal, 1979.

Revolucionários italianos no Império do Brasil. In: A revolução farroupilha: história \& interpretação. Porto Alegre: Mercado Aberto, 1985, p. 98-109.

MAYER, Jorge M. Alberdi y su tiempo. Buenos Aires: Editorial Universitaria de Buenos Aires, 1963.

ORTIZ, Fernando. Contrapunteo cubano del tabaco y el azucar. Habana: Consejo Nacional de Cultura La Habana, 1963.

PRADO, Maria Ligia Coelho. América Latina no século XIX: tramas, telas e textos. São Paulo/Bauru: Edusp/Edusc, 1999.

PRATT, Mary Louise. Os olhos do império: relatos de viagem e transculturação. Bauru: EDUSC, 1999.

REICHEL, Heloisa Jochims e GUTFREIND, Ieda. As raízes históricas do Mercosul: a Região Platina colonial. São Leopoldo: UNISINOS, 1996.

SAFFORD, Frank. Política, ideologia e sociedade na América espanhola do pósindependência. In: BETHELL, Leslie. (org.). História da América Latina. Vol. 3: da Independência até 1870. São Paulo/Brasília: Edusp/Imprensa Oficial/ Funag, 2001, p. 329-412.

SALA DE TOURON, Lucía e ALONSO ELOY, Rosa. El Uruguay comercial, pastoril y caudillesco. Tomo II: sociedad, política e ideologia. Montevidéu: Ediciones de la Banda Oriental, 1991. 
SCHEIDT, Eduardo. Concepções de República na Região Platina à época da Revolução Farroupilha. Dissertação de mestrado. São Leopoldo: UNISINOS, 2000. Mimeo.

Idéias da "geração de 1837" na imprensa farroupilha rio-grandense. In: Estudos Leopoldenses: série História. Revista do Programa de PósGraduação em História da Universidade do Vale do Rio dos Sinos. São Leopoldo: v. 3, n. ${ }^{\circ}$ 1, 1999, p.67-78.

Representações de nação por periodistas italianos na Região Platina (1827-1860). Tese de doutorado. São Paulo: USP, 2004. Mimeo.

Republicanismo na Região Platina à época da Revolução Farroupilha: um estudo de história comparada. In: HEINZ, Flavio M. e HERRLEIN JR., Ronaldo. Histórias Regionais do Cone Sul. Santa Cruz do Sul: EDUNISC, 2003, p. 167-190.

VARELA, Alfredo. História da grande revolução: o cyclo farroupilha no Brasil. Porto Alegre: Globo, 1933. 6 v.

WASSERMAN, Fabio. Formas de identidad politica y representaciones de la nación en el discurso de la Generación de 1837.Tese de licenciatura. Buenos Aires: UBA, 1996. Mimeo. 